\title{
Analisis Perbandingan Metode TOPSIS dan SAW pada Penilaian Karyawan (Studi Kasus : PT Pura Barutama Unit Paper Mill 5, 6, 9)
}

\author{
Geraldie Tanu Saputra ${ }^{1}$, Magdalena A. Ineke Pakereng ${ }^{2}$ \\ 1,2Fakultas Teknologi Informasi, Universitas Kristen Satya Wacana \\ e-mail: ${ }^{1672016190 @ s t u d e n t . u k s w . e d u, ~}{ }^{2}$ ineke.pakereng@uksw.edu
}

\begin{abstract}
Abstrak
PT Pura Barutama Unit Paper Mill 5, 6, 9 adalah salah satu anak perusahaan dari Pura Group dimana unit tersebut beroperasi dalam memproduksi kertas. Dalam melakukan peniliaian kinerja karyawan dalam unit tersebut, digunakanlah sebuah Sistem Pendukung Keputusan dengan Metode Simple Addtive Weighting (SAW). Akan tetapi, terkadang sulit untuk menentukan batas minimal nilai yang baik pada hasil penilaian dengan metode SAW yang telah berjalan, dikarenakan hasil penilaian karyawan antara satu sama lain tidak jauh berbeda. Multi Criteria Decision Making (MCDM) adalah model yang sering digunakan untuk mengambil keputusan yang memiliki beberapa kriteria yang harus dipertimbangkan. TOPSIS adalah salah satu dari metode MCDM pada Sistem Pendukung Keputusan (SPK) yang populer yang sudah digunakan dibanyak bidang. Salah satunya adalah bidang human resource seperti penilaian kinerja karyawan. Metode SAW juga adalah satu metode MCDM yang sering digunakan. Penelitian ini bertujuan untuk menganalisis dan membandingkan hasil akhir nilai preferensi dan urutan peringkat dari penilaian kinerja karyawan dengan metode TOPSIS dan SAW pada perusahaan PT Pura Barutama Unit Paper Mill 5, 6, 9. Hasil akhir menunjukan bahwa metode TOPSIS memiliki nilai preferensi yang lebih variatif dibandingkan dengan metode SAW. Walaupun perbedaan peringkat yang dihasilkan oleh kedua metode tidak terlalu berbeda, tetapi metode TOPSIS bisa dijadikan alternatif pengganti metode yang digunakan dalam penilaian kinerja karyawan pada PT Pura Barutama Unit Paper Mill 5, 6, 9.
\end{abstract}

Kata Kunci: Sistem Pendukung Keputusan (SPK), Penilaian Kinerja Karyawan, Multi Criteria Decision Making (MCDM

\begin{abstract}
PT Pura Barutama Unit Paper Mill 5, 6, 9 is a subsidiary of Pura Group where the unit operates in producing paper. In order to do employee performance appraisal in that unit, Decision Support System with Simple Additive Weighting (SAW) method is needed. However, sometimes it's hard to decide the minimum score limit on the result with current SAW method, because the employee appraisal result between each other is not too different. Multi Criteria Decision Making (MCDM) is a model that is often used to make decisions in which several criteria must be considered. TOPSIS is one of the most popular MCDM methods on Decison Support System (DSS) that have been used in many fields. For example, they have been applied in the field of human resources, such as in employee performance appraisal. The SAW method is also a MCDM method that is often used. This study aims to analyze and compare the final results of the preference values and ranking order of employee performance appraisal determined using the TOPSIS and SAW methods at PT Pura Barutama Unit Paper Mill 5, 6, 9. The final results show that the TOPSIS method leads to a more varied preference value compared to the SAW method. Although the ranking produced by the two methods are not so different, the TOPSIS method can be used as an alternative to the method used in employee performance appraisal at PT Pura Barutama Unit Paper Mill 5, 6, 9.
\end{abstract}

Keywords: Decision Support System (DSS), Employee Performance Appraisal, Multi Criteria Decision Making (MCDM) 


\section{Pendahuluan}

Karyawan yang bekerja dalam suatu instansi sudah seharusnya mendapat apresiasi. Salah cara untuk mengetahui karyawan mana saja yang berhak untuk mendapat apresiasi adalah melalui penilaian karyawan atau bisa disebut juga penilaian kinerja. Penilaian kinerja atau performance appraisal adalah sebuah sistem yang digunakan untuk menilai prestasi ataupun performa dari seorang karyawan dalam rentang waktu tertentu (Setiobudi, 2017). Selain itu, penilaian kinerja dapat digunakan sebagai tolak ukur, dan identifikasi kelebihan serta kekurangan yang dimiliki oleh seorang karyawan (Setiobudi, 2017). Dengan adanya penilaian kinerja karyawan yang optimal dan efektif, karyawan dapat termotivasi dalam bekerja sehari-hari. Akan tetapi, jika penilaian kinerja karyawan yang dilakukan tidak optimal dan efektif, maka akan terjadi keluhan karyawan, turunnya motivasi kerja karyawan, hingga tingginya intensi turnover karyawan (Evita, Muizu, \& Atmojo, 2017). PT Pura Barutama sendiri berawal dari sebuah percetakan letterpress pada tahun 1908 (Auxyllian \& Susetyo, 2019). Kemudian pada tahun 1970, Bapak Jacobus Busono memimpin perusahaan ini sampai berkembang pesat menjadi industri modern Pura Group yang terkenal dengan industri pemropuduksi kertas security-nya (Auxyllian \& Susetyo, 2019) Salah satu anak perusahaan dari Pura Group adalah PT Pura Barutama Unit Paper Mill 5, 6, 9 yang bergerak pada bidang industri kertas dengan total karyawan kurang lebih 500 orang (Auxyllian \& Susetyo, 2019).

Pada awalnya penilaian kinerja karyawan di Unit Paper Mill 5, 6, 9 masih menggunakan form yang mengharuskan pimpiman-pimpinan dari setiap departemen untuk menilai karyawannya (Auxyllian \& Susetyo, 2019). Untuk sekarang penilaian kinerja karyawan yang saat ini dijalankan pada Unit Paper Mill 5, 6, 9 adalah penilaian kinerja karyawan yang berbasis web yang berjalan di server utama Pura Group. Penilaian kinerja karyawan yang berbasis web tersebut tidak hanya membuat penilaian menjadi lebih mudah tetapi juga menggunakan Sistem Pendukung Keputusan (SPK) dengan metode Simple Additive Weighting agar penilaian menjadi lebih obyektif.

Dari sistem penilaian kinerja karyawan yang sudah ada di Unit Paper
Mill 5, 6, 9 akan dibandingkan dengan sebuah metode SPK lain yaitu metode Technique for Order of Preference by Similarity to Ideal Solution (TOPSIS). Metode dalam SPK seperti TOPSIS, SAW, dan beberapa metode SPK lainnya digunakan dalam sebuah penelitian untuk menentukan penempatan karyawan (Bidang Human Resource). Hasilnya TOPSIS mampu memberikan nilai akurasi sekitar 95\%, dan SAW mampu memberikan nilai akurasi sekitar $81.67 \%$ (Widianta, Rizaldi, Setyohadi, \& Riskiawan, 2018). Metode TOPSIS sendiri sudah digunakan dalam logistik, teknik dan manufakturing, manajemen bisnis dan marketing, sumber daya manusia (Human Resource), dan manajemen sumber daya air (Velasquez \& Hester, 2013). Dalam penelitian untuk menentukan laboratorium yang paling baik digunakan dalam penelitian sains, digunakan dua metode SPK yaitu Analytical Hierarchy Process (AHP) dan TOPSIS. Hasilnya menunjukan bahwa TOPSIS mampu meminimalisir upaya dan membantu pengambil keputusan, dengan nilai perhitungan distribusi TOPSIS yang menunjukan interval yang lebih tinggi dibandingkan AHP (Mohamed, Bouikhalene, Ouatik, \& Safi, 2019).

Penelitian ini bertujuan dan berfokus untuk membandingkan metode TOPSIS untuk menjadi metode alternatif pengganti dengan metode SAW yang sudah berjalan di PT Pura Barutama Unit Paper Mill 5, 6, 9. Dari dua metode yaitu SAW dan TOPSIS akan dibandingkan dari segi output yang dihasilkan dari tiap metode. Output yang dianalisis adalah bagian penentuan peringkat dari setiap karyawan (alternatif), dan nilai preferensi yang dihasilkan dari kedua metode tersebut.

\section{Metode Penelitian}

1. Mutli Criteria Decision Making (MCDM) Multi Criteria Decision Making atau MCDM adalah suatu metode pada Sistem Pendukung Keputusan (SPK) yang sudah sering digunakan untuk menyelesaikan masalah yang memiliki beberapa kriteria dalam penentuannya, dan sering digunakan pada bidang ekonomi, pengelolaan sumber daya manusia, politik, transpotasi, dan teknologi informasi (contohnya: heterogen jaringan nirkabel) (Anwar, Masud, UI Islam Khan, Olanrewaju, \& Latif, 2018). Sistem Pendukung Keputusan (SPK) sendiri sering dijadikan alat bantu bagi para pengambil 
keputusan, yaitu sebagai alat untuk memperluas kapabilitas para pengambil keputusan, tetapi tidak menggantikan penilaian mereka (Aeni Hidayah \& Fetrina, 2017). Pada dasarnya MCDM terdiri dari 2 struktur fase. Fase pertama melibatkan konstruksi dan kompilasi dari matriks evaluasi yang terdiri dari berbagai alternatif dan kinerjanya, berdasarkan berbagai kriteria dan sub-kriteria (dan bobotnya), ditambah indikator penilaian dari penilai. Fase kedua adalah mengolah data dalam matriks evaluasi untuk mengevaluasi alternatif, berdasarkan tujuan yang ingin dicapai (Guarini, Battisti, \& Chiovitti, 2018). Terdapat beberapa metode yang sering digunakan dalam melakukan penilaian kinerja karyawan, seperti teknik statistika, pemodelan skor, Analytical Hierarchy Process (AHP), TOPSIS, ELECTRE, Simple Additive Weighting (SAW), dan PROMETHEE (Auxyllian \& Susetyo, 2019; Bogdanovic \& Miletic, 2015).

2. Metode Technique for Order of Preference by Similarity to Ideal Solution (TOPSIS)

Metode TOPSIS adalah salah satu metode dari sistem pengambil keputusan dari banyak kriteria yang ditemukan oleh Hwang dan Yoon pada tahun 1981 (Adi, Sugiharti, \& Alamsyah, 2018). Metode TOPSIS adalah metode yang berprinsip bahwa alternatif yang terpilih harus mempunyai jarak terpendek dari solusi ideal positif dan mempunyai jarak terjauh dari solusi ideal negatif (Rahim et al., 2018). Jarak terdekat atau terpendek suatu alternatif dengan solusi optimal (solusi ideal positif dan solusi ideal negatif) tersebut dihitung dengan menggunakan rumus Euclidean Distance (Bambang, Wijaya, Wahyono, Nugrahesthy, \& Hapsari, 2019). Metode TOPSIS sendiri sudah sering digunakan secara umum sebagai metode sistem pendukung keputusan karena kemudahannya dalam diterapkan, mudah dimengerti, dan efesien (Adi et al., 2018; Velasquez \& Hester, 2013). Tahapan dan rumus yang digunakan dalam metode TOPSIS adalah (Adi et al., 2018):

1) Buat matriks keputusan yang ternormalisasi dengan rumus persamaan (1)

$$
r_{i j}=\frac{x_{i j}}{\sqrt{\sum_{i=1}^{m} x_{i j}^{2}}}
$$

$r_{i j}=$ hasil nilai normalisasi dari matriks keputusan

$X_{i j}=$ nilai original dari matriks keputusan

2) Buat matriks keputusan terbobot yang ternormalisasi dengan rumus persamaan (2)

$$
y_{i j}=w_{j} r_{i j}
$$

Dimana:

$\mathrm{y}_{\mathrm{ij}}=$ hasil nilai dari matriks keputusan ternormalisasi yang digabung dengan bobot kriteria

$\mathrm{w}_{\mathrm{j}}=$ bobot pada kriteria ke-j

$r_{i j}=$ nilai dari matriks keputusan yang ternomalisasi

3) Menentukan matriks solusi ideal positif dan matriks solusi ideal negatif dengan ketentuan (3) dan (4):

$$
\begin{gathered}
A^{+}=\left(y_{1}{ }^{+}, y_{2}{ }^{+}, \ldots, y_{n}{ }^{+}\right) ; \\
A^{-}=\left(y_{1}{ }^{-}, y_{2}{ }^{-}, \ldots, y_{n}{ }^{-}\right) ;
\end{gathered}
$$

$y_{1}{ }^{+}=\left\{\begin{array}{c}\max _{i y i j} ; \text { Jika } j \text { adalah atribut benefit } \\ \min _{\text {iyij } j} ; \text { Jika } j \text { adalah atribut cost }\end{array}\right.$

$y_{1}{ }^{-}=\left\{\begin{array}{c}\max _{i y i j} ; \text {;ika } j \text { adalah atribut benefit } \\ \text { min }_{\text {iyij }} \text {; Jika } j \text { adalah atribut cost }\end{array}\right.$

Dimana:

$\mathrm{A}^{+}=$matriks $\mathrm{A}^{+}$solusi ideal positif

$A^{-}=$matriks $A^{-}$solusi ideal negatif

$\mathrm{y}_{1}{ }^{+}=$Max $\mathrm{y}_{\mathrm{ij}}$ jika j adalah atribut benefit

Max $\mathrm{y}_{\mathrm{ij}}=$ jika $\mathrm{j}$ adalah atribut cost

$\mathrm{y}_{1}{ }^{-}=$Min $\mathrm{y}_{\mathrm{ij}}$ jika j adalah atribut benefit

Min $\mathrm{y}_{\mathrm{ij}}=$ jika $\mathrm{j}$ adalah atribut cost

4) Menentukan jarak antara nilai setiap alternatif dengan matriks solusi ideal positif dan matriks solusi ideal negatif menggunakan Euclidean Distance :

$$
\begin{aligned}
& {D_{i}}^{+}=\sqrt{\sum_{j=1}^{n}\left(y_{i}^{+}-y_{i j}\right)^{2}} \\
& D_{i}^{-}=\sqrt{\sum_{j=1}^{n}\left(y_{i j}-y_{i}^{-}\right)^{2}}
\end{aligned}
$$

Dimana:

$D_{i}^{+}=$Jarak ke solusi ideal positif

$\mathrm{D}_{\mathrm{i}}{ }^{-}=$Jarak ke solusi ideal negatif

5) Menghitung nilai preferensi untuk setiap alternatif dengan rumus persamaan (7) :

$$
V_{i}=\frac{D_{i}^{-}}{D_{i}^{-}-D_{i}^{+}}
$$

Nilai prefensi $\left(\mathrm{V}_{\mathrm{i}}\right)$ adalah nilai akhir yang digunakan untuk menentukan peringkat dari seluruh alternatif yang telah dihitung. Dengan nilai $V_{i}$ yang paling tinggi adalah alternatif yang paling baik.

Dimana: 


\section{Metode Simple Additive Weighting} (SAW)

Metode SAW sering juga diketahui sebagai metode penjumlahan berbobot (Wira Trise Putra \& Agustian Punggara, 2018). Konsep dasarnya adalah menghitung penjumlahan terbobot dari rating kinerja pada setiap atribut (Auxyllian \& Susetyo, 2019). Kelebihan menggunakan metode SAW dibandingkan dengan metode SPK lainnya adalah kemampuannya untuk memberikan penilaian yang tepat karena didasarkan pada nilai yang sudah ditentukan sebelumnya, serta bobot dari tiap kriteria atau atribut (Wira Trise Putra \& Agustian Punggara, 2018). Metode SAW sendiri sudah sering digunakan, contohnya dalam bidang pengelolaan sumber air, bisnis, dan manajemen finansial (Velasquez \& Hester, 2013). Dalam metode ini, sebuah Decision Matrix (D) dibentuk untuk menghitung nilai dari kriteria atau attribute untuk setiap alternatif yang dipakai untuk menentukan peringkat. Kemudian Normalized Decision Matrix (D') berasal dari hasil perhitungan normalisasi dari kriteria/atribut yang menguntungkan (benefit), dan kriteria/atribut yang merugikan (worst) (Annette, Banu W, \& Chandran $P$, 2018). Rumus untuk menghitung kriteria/atribut dari metode Simple Additive Weighting adalah (Auxyllian \& Susetyo, 2019; Wira Trise Putra \& Agustian Punggara, 2018) :

$R i j=\left\{\begin{array}{c}\frac{X_{i j}}{\operatorname{Max} X_{i j}} \text { Jika } j \text { adalah atribut (keuntungan) } / \text { benefit } \\ \left.\frac{\text { Min } X_{i j}}{X_{i j}} \text { Jika } j \text { adalah atribut (biaya) }\right) / \text { cost }\end{array}\right.$ Dimana :

$\mathrm{R}_{\mathrm{ij}}=$ Rating kinerja ternormalisasi

$M a x_{i j}=$ Nilai maksimum dari setiap baris dan kolom

$\mathrm{Min}_{\mathrm{ij}}=$ Nilai minimum dari setiap baris dan kolom

$X_{i j}=$ Nilai matriks pada baris ke-i dan kolom ke-j dengan $R_{i j}$ adalah rating kinerja ternormalisasi dari alternatif $A_{i}$ pada atribut atau kriteria $C_{j} ; i=1,2, \ldots, m$ dan $j=1,2, \ldots, n$.

Untuk menghitung bobot alternatif terhadap bobot kriteria/atribut dari metode Simple Additve Weighting adalah sebagai berikut :

$$
V_{i}=\sum_{j=1}^{n} W_{j} \cdot R_{i j}
$$

Dimana:

$V_{i}=$ nilai akhir (preferensi) dari alternatif

$\mathrm{W}_{\mathrm{j}}=$ nilai bobot yang telah ditentukan untuk setiap kreteria atau atribut
$R_{i j}=$ nilai dari matriks yang ternomalisasi pada baris ke-i dan kolom ke-j

Dengan nilai $V_{i}$ yang paling tinggi adalah nilai preferensi dari sebuah alternatif yang paling baik.

\section{Alur/Tahapan Penelitian}

Tahapan penelitian yang telah dirancang dan digunakan dalam melakukan analisa output penilaian kinerja karyawan sesuai dengan gambar 1. Berikut adalah penjelasan dari setiap alur :

1) Pengumpulan data karyawan dan kriteria apa saja yang akan dinilai dari karyawan.

2) Menilai karyawan sesuai dengan kriteria yang ingin dinilai.

3) Pemberian bobot untuk setiap kriteria yang akan dinilai.

4) Perhitungan TOPSIS dan SAW untuk penilaian kinerja karyawan, serta hasil peringkat yang dikeluarkan oleh setiap metode.

5) Melakukan analisis perbandingan setiap output yang dihasilkan berdasarkan peringkat karyawan, dan kesenjangan nilai yang dihasilkan dari kedua metode.

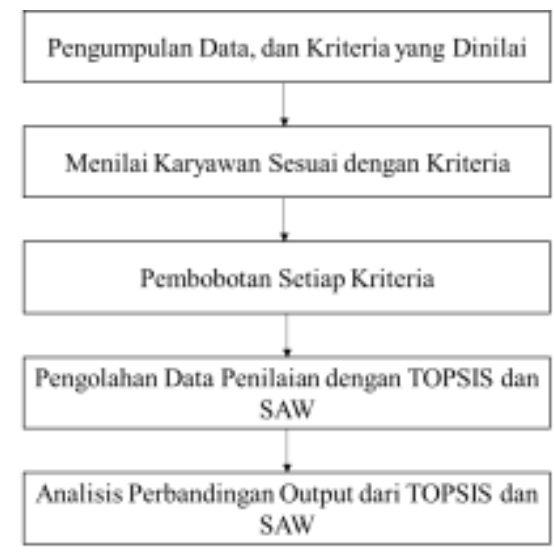

Gambar 1. Diagram alur analisa output penilaian kinerja karyawan

\section{Hasil dan Pembahasan}

Kriteria yang digunakan dalam percobaan dan perhitungan adalah kriteria yang sudah digunakan pada tempat studi kasus, dan bobot tersebut sudah ditetapkan oleh tempat studi kasus yang diteliti. Berikut adalah tabel dari kriteria beserta bobotnya: 
Tabel 1. Daftar Kriteria Dan Bobotnya

\begin{tabular}{|c|c|c|}
\hline Nama Kriteria & $\begin{array}{c}\text { Alias } \\
\text { Kriteria }\end{array}$ & $\begin{array}{c}\text { Bobot } \\
\text { Kriteria }\end{array}$ \\
\hline Kerjasama & C1 & 0.05 \\
\hline Kedisiplinan/Kepatuhan & C2 & 0.05 \\
\hline K3 & C3 & 0.05 \\
\hline Absensi & C4 & 0.05 \\
\hline Pemahaman Tugas & C5 & 0.1 \\
\hline Pencapaian Hasil & C6 & 0.25 \\
\hline Efektifitas & C7 & 0.15 \\
\hline Kreatifitas & C8 & 0.15 \\
\hline Ketuntasan & C9 & 0.15 \\
\hline
\end{tabular}

Tabel 1 adalah tabel dari pembobotan setiap kriteria yang dinilai. Dimana jika bobot kriteria dijumlahkan maka akan menghasilkan nilai 1 atau $100 \%$. Untuk sifat kriteria yang digunakan adalah benefit atau keuntungan.

\section{Hasil}

Data yang digunakan untuk penelitian adalah data penilaian kinerja karyawan yang telah dinilai oleh manajer yang didapat dari tempat studi kasus. Data dapat dilihat di tabel 2.

Tabel 2. Data Penilaian Awal Kinerja Karyawan

\begin{tabular}{|c|c|c|c|c|c|c|c|c|c|}
\hline & C1 & C2 & C3 & C4 & C5 & C6 & C7 & C8 & C9 \\
\hline P1 & 0.6 & 0.6 & 0.6 & 0.4 & 0.8 & 0.8 & 0.8 & 0.6 & 0.8 \\
\hline P2 & 0.4 & 0.6 & 0.6 & 1 & 0.8 & 0.6 & 0.6 & 0.4 & 0.6 \\
\hline P3 & 1 & 0.6 & 0.4 & 0.4 & 0.8 & 0.6 & 0.6 & 0.6 & 0.6 \\
\hline P4 & 0.6 & 0.6 & 0.4 & 0.6 & 0.8 & 0.6 & 0.6 & 0.8 & 0.6 \\
\hline P5 & 1 & 0.8 & 0.6 & 0.8 & 0.8 & 0.8 & 0.8 & 0.8 & 0.8 \\
\hline P6 & 0.8 & 0.8 & 0.6 & 0.8 & 1 & 0.8 & 0.8 & 0.6 & 0.8 \\
\hline P7 & 0.6 & 0.6 & 0.6 & 0.6 & 0.8 & 0.8 & 0.6 & 0.6 & 0.8 \\
\hline P8 & 0.6 & 0.4 & 0.6 & 0.6 & 0.8 & 0.8 & 0.8 & 0.8 & 0.8 \\
\hline P9 & 0.8 & 0.8 & 0.8 & 0.8 & 1 & 0.6 & 0.8 & 0.8 & 0.8 \\
\hline P10 & 0.6 & 0.8 & 0.8 & 0.6 & 1 & 0.8 & 0.6 & 0.8 & 0.8 \\
\hline P11 & 0.8 & 1 & 0.6 & 0.8 & 0.6 & 0.8 & 0.8 & 0.8 & 0.8 \\
\hline P12 & 0.8 & 0.8 & 0.6 & 0.8 & 1 & 0.8 & 0.8 & 1 & 0.8 \\
\hline P13 & 0.8 & 0.8 & 0.6 & 0.8 & 0.8 & 0.8 & 0.8 & 1 & 0.8 \\
\hline P14 & 0.8 & 0.6 & 0.6 & 0.8 & 1 & 0.8 & 0.8 & 0.8 & 0.8 \\
\hline P15 & 0.8 & 0.8 & 0.6 & 0.8 & 0.8 & 0.8 & 0.8 & 0.8 & 0.8 \\
\hline
\end{tabular}

Setelah data telah dikumpulkan, perhitungan terhadap data yang telah dikumpulkan akan dilakukan dengan metode TOPSIS. Berikut adalah perhitungan SPK dengan metode TOPSIS:
1) Hitung matriks yang ternormalisasi dengan persamaan 1 akan menghasilkan matriks dalam bentuk tabel seperti berikut :

Tabel 3. Tabel Hasil Matriks Normalisasi

\begin{tabular}{|c|c|c|c|c|c|c|c|c|c|}
\hline Alternatif & C1 & C2 & C3 & C4 & C5 & C6 & C7 & C8 & C9 \\
\hline P1 & 0.2065 & 0.2148 & 0.2545 & 0.1425 & 0.2399 & 0.2747 & 0.2794 & 0.2032 & 0.2703 \\
\hline P2 & 0.1377 & 0.2148 & 0.2545 & 0.3562 & 0.2399 & 0.206 & 0.2095 & 0.1355 & 0.2027 \\
\hline P3 & 0.3442 & 0.2148 & 0.1696 & 0.1425 & 0.2399 & 0.206 & 0.2095 & 0.2032 & 0.2027 \\
\hline P4 & 0.2065 & 0.2148 & 0.1696 & 0.2137 & 0.2399 & 0.206 & 0.2095 & 0.2709 & 0.2027 \\
\hline P5 & 0.3442 & 0.2864 & 0.2545 & 0.285 & 0.2399 & 0.2747 & 0.2794 & 0.2709 & 0.2703 \\
\hline P6 & 0.2754 & 0.2864 & 0.2545 & 0.285 & 0.2999 & 0.2747 & 0.2794 & 0.2032 & 0.2703 \\
\hline P7 & 0.2065 & 0.2148 & 0.2545 & 0.2137 & 0.2399 & 0.2747 & 0.2095 & 0.2032 & 0.2703 \\
\hline P8 & 0.2065 & 0.1432 & 0.2545 & 0.2137 & 0.2399 & 0.2747 & 0.2794 & 0.2709 & 0.2703 \\
\hline P9 & 0.2754 & 0.2864 & 0.3393 & 0.285 & 0.2999 & 0.206 & 0.2794 & 0.2709 & 0.2703 \\
\hline P10 & 0.2065 & 0.2864 & 0.3393 & 0.2137 & 0.2999 & 0.2747 & 0.2095 & 0.2709 & 0.2703 \\
\hline P11 & 0.2754 & 0.3581 & 0.2545 & 0.285 & 0.1799 & 0.2747 & 0.2794 & 0.2709 & 0.2703 \\
\hline P12 & 0.2754 & 0.2864 & 0.2545 & 0.285 & 0.2999 & 0.2747 & 0.2794 & 0.3386 & 0.2703 \\
\hline P13 & 0.2754 & 0.2864 & 0.2545 & 0.285 & 0.2399 & 0.2747 & 0.2794 & 0.3386 & 0.2703 \\
\hline P14 & 0.2754 & 0.2148 & 0.2545 & 0.285 & 0.2999 & 0.2747 & 0.2794 & 0.2709 & 0.2703 \\
\hline P15 & 0.2754 & 0.2864 & 0.2545 & 0.285 & 0.2399 & 0.2747 & 0.2794 & 0.2709 & 0.2703 \\
\hline
\end{tabular}


2) Hitung matriks keputusan terbobot yang ternormalisasi dengan rumus persamaan 2 :

Tabel 4. Tabel Hasil Matriks Normalisasi Terbobot

\begin{tabular}{|c|c|c|c|c|c|c|c|c|c|}
\hline Alternatif & C1 & C2 & C3 & C4 & C5 & C6 & C7 & C8 & C9 \\
\hline P1 & 0.0103 & 0.0107 & 0.0127 & 0.0071 & 0.024 & 0.0687 & 0.0419 & 0.0305 & 0.0405 \\
\hline P2 & 0.0069 & 0.0107 & 0.0127 & 0.0178 & 0.024 & 0.0515 & 0.0314 & 0.0203 & 0.0304 \\
\hline P3 & 0.0172 & 0.0107 & 0.0085 & 0.0071 & 0.024 & 0.0515 & 0.0314 & 0.0305 & 0.0304 \\
\hline P4 & 0.0103 & 0.0107 & 0.0085 & 0.0107 & 0.024 & 0.0515 & 0.0314 & 0.0406 & 0.0304 \\
\hline P5 & 0.0172 & 0.0143 & 0.0127 & 0.0142 & 0.024 & 0.0687 & 0.0419 & 0.0406 & 0.0405 \\
\hline P6 & 0.0138 & 0.0143 & 0.0127 & 0.0142 & 0.03 & 0.0687 & 0.0419 & 0.0305 & 0.0405 \\
\hline P7 & 0.0103 & 0.0107 & 0.0127 & 0.0107 & 0.024 & 0.0687 & 0.0314 & 0.0305 & 0.0405 \\
\hline P8 & 0.0103 & 0.0072 & 0.0127 & 0.0107 & 0.024 & 0.0687 & 0.0419 & 0.0406 & 0.0405 \\
\hline P9 & 0.0138 & 0.0143 & 0.017 & 0.0142 & 0.03 & 0.0515 & 0.0419 & 0.0406 & 0.0405 \\
\hline P10 & 0.0103 & 0.0143 & 0.017 & 0.0107 & 0.03 & 0.0687 & 0.0314 & 0.0406 & 0.0405 \\
\hline P11 & 0.0138 & 0.0179 & 0.0127 & 0.0142 & 0.018 & 0.0687 & 0.0419 & 0.0406 & 0.0405 \\
\hline P12 & 0.0138 & 0.0143 & 0.0127 & 0.0142 & 0.03 & 0.0687 & 0.0419 & 0.0508 & 0.0405 \\
\hline P13 & 0.0138 & 0.0143 & 0.0127 & 0.0142 & 0.024 & 0.0687 & 0.0419 & 0.0508 & 0.0405 \\
\hline P14 & 0.0138 & 0.0107 & 0.0127 & 0.0142 & 0.03 & 0.0687 & 0.0419 & 0.0406 & 0.0405 \\
\hline P15 & 0.0138 & 0.0143 & 0.0127 & 0.0142 & 0.024 & 0.0687 & 0.0419 & 0.0406 & 0.0405 \\
\hline
\end{tabular}

3) Mencari kandidat solusi ideal positif dan kandidat solusi ideal negatif

dengan menggunakan ketentuan 3 dan 4:

Tabel 5. Tabel Kandidat Solusi Ideal Positif Dan Solusi Ideal Negatif

\begin{tabular}{|c|c|c|c|}
\hline Kriteria & $\begin{array}{c}\text { Kandidat Solusi } \\
\text { Ideal }\end{array}$ & $\operatorname{Max}\left(\mathrm{A}^{+}\right)$ & $\operatorname{Min}\left(A^{-}\right)$ \\
\hline C1 & $\begin{array}{c}0.0103 ; 0.0069 ; \\
0.0172 ; 0.0103 ; \\
0.0172 ; 0.0138 ; \\
0.0103 ; 0.0103 ; \\
0.0138 ; 0.0103 ; \\
0.0138 ; 0.0138 ; \\
0.0138 ; 0.0138 ; \\
\quad 0.0138 ;\end{array}$ & 0.0172 & 0.0069 \\
\hline C2 & $\begin{array}{c}0.0107 ; 0.0107 ; \\
0.0107 ; 0.0107 ; \\
0.0143 ; 0.0143 ; \\
0.0107 ; 0.0072 ; \\
0.0143 ; 0.0143 ; \\
0.0179 ; 0.0143 ; \\
0.0143 ; 0.0107 ; \\
0.0143 ;\end{array}$ & 0.0179 & 0.0072 \\
\hline C3 & $\begin{array}{c}0.0127 ; 0.0127 ; \\
0.0085 ; 0.0085 ; \\
0.0127 ; 0.0127 ; \\
0.0127 ; 0.0127 ; \\
0.017 ; 0.017 ; 0.0127 ; \\
0.0127 ; 0.0127 ; \\
0.0127 ; 0.0127 ;\end{array}$ & 0.017 & 0.0085 \\
\hline C4 & $\begin{array}{l}\text { 0.0071; 0.0178; } \\
\text { 0.0071; } 0.0107 \\
0.0142 ; 0.0142 \\
0.0107 ; 0.0107\end{array}$ & 0.0178 & 0.0071 \\
\hline
\end{tabular}




\begin{tabular}{|c|c|c|c|}
\hline & $\begin{array}{c}0.0142 ; 0.0107 ; \\
0.0142 ; 0.0142 ; \\
0.0142 ; 0.0142 ; \\
0.0142 ;\end{array}$ & & \\
\hline C5 & $\begin{array}{c}0.024 ; 0.024 ; 0.024 \\
0.024 ; 0.024 ; 0.03 \\
0.024 ; 0.024 ; 0.03 \\
0.03 ; 0.018 ; 0.03 ; \\
0.024 ; 0.03 ; 0.024\end{array}$ & 0.03 & 0.018 \\
\hline C6 & $\begin{array}{c}0.0687 ; 0.0515 ; \\
0.0515 ; 0.0515 \\
0.0687 ; 0.0687 \\
0.0687 ; 0.0687 \\
0.0515 ; 0.0687 \\
0.0687 ; 0.0687 \\
0.0687 ; 0.0687 \\
0.0687 ;\end{array}$ & 0.0687 & 0.0515 \\
\hline C7 & $\begin{array}{c}0.0419 ; 0.0314 ; \\
0.0314 ; 0.0314 ; \\
0.0419 ; 0.0419 \\
0.0314 ; 0.0419 ; \\
0.0419 ; 0.0314 ; \\
0.0419 ; 0.0419 ; \\
0.0419 ; 0.0419 ; \\
0.0419 ;\end{array}$ & 0.0419 & 0.0314 \\
\hline C8 & $\begin{array}{c}0.0305 ; 0.0203 \\
0.0305 ; 0.0406 \\
0.0406 ; 0.0305 \\
0.0305 ; 0.0406 \\
0.0406 ; 0.0406 \\
0.0406 ; 0.0508 ; \\
0.0508 ; 0.0406 \\
0.0406 ;\end{array}$ & 0.0508 & 0.0203 \\
\hline C9 & $\begin{array}{c}0.0405 ; 0.0304 ; \\
0.0304 ; 0.0304 ; \\
0.0405 ; 0.0405 \\
0.0405 ; 0.0405 \\
0.0405 ; 0.0405 ; \\
0.0405 ; 0.0405 \\
0.0405 ; 0.0405 \\
0.0405 ;\end{array}$ & 0.0405 & 0.0304 \\
\hline
\end{tabular}

4) Mencari jarak antara nilai setiap alternatif dengan matriks solusi ideal positif dan matriks solusi ideal negatif menggunakan persamaan 5 dan persamaan 6 :

Tabel 6. Jarak Antara Solusi Ideal Positif Dan Solusi Ideal Negatif Tiap Alternatif

\begin{tabular}{|c|c|c|}
\hline Alternatif & $\mathbf{D}^{+}$ & $\mathbf{D}^{-}$ \\
\hline P1 & 0.0261 & 0.0263 \\
\hline P2 & 0.0406 & 0.0135 \\
\hline P3 & 0.0345 & 0.0161 \\
\hline P4 & 0.0295 & 0.0220 \\
\hline P5 & 0.0135 & 0.0344 \\
\hline P6 & 0.0216 & 0.0304 \\
\hline
\end{tabular}

\begin{tabular}{|c|l|l|}
\hline P7 & 0.0269 & 0.0243 \\
\hline P8 & 0.0193 & 0.0316 \\
\hline P9 & 0.0209 & 0.0315 \\
\hline P10 & 0.0180 & 0.0332 \\
\hline P11 & 0.0170 & 0.0339 \\
\hline P12 & 0.0074 & 0.0418 \\
\hline P13 & 0.0096 & 0.0405 \\
\hline P14 & 0.0140 & 0.0345 \\
\hline P15 & 0.0139 & 0.0335 \\
\hline
\end{tabular}

5) Menghitung nilai preferensi dari setiap alternatif dengan persamaan 7, kemudian diurutkan dari nilai preferensi terbesar ke nilai preferensi terkecil: 
Tabel 7. Nilai Prefensi Dan Ranking

\begin{tabular}{|c|c|c|}
\hline Ranking & Alternatif & $\begin{array}{c}\text { Nilai } \\
\text { Preferensi }\end{array}$ \\
\hline 1 & P12 & 0.8489 \\
\hline 2 & P13 & 0.8091 \\
\hline 3 & P5 & 0.7179 \\
\hline 4 & P14 & 0.7110 \\
\hline 5 & P15 & 0.7062 \\
\hline 6 & P11 & 0.6660 \\
\hline 7 & P10 & 0.6484 \\
\hline 8 & P8 & 0.6214 \\
\hline 9 & P9 & 0.6013 \\
\hline
\end{tabular}

\begin{tabular}{|l|l|l|}
\hline 10 & P6 & 0.5839 \\
\hline 11 & P1 & 0.5017 \\
\hline 12 & P7 & 0.4745 \\
\hline 13 & P4 & 0.4281 \\
\hline 14 & P3 & 0.3176 \\
\hline 15 & P2 & 0.2489 \\
\hline
\end{tabular}

\section{Pembahasan}

Analisis yang dilakukan adalah analisis perbandingan hasil akhir peringkat jika perhitungan menggunakan metode TOPSIS dan jika perhitungan menggunakan metode SAW dapat dilihat pada tabel 8 .

Tabel 8. Perbandingan TOPSIS Dan SAW

\begin{tabular}{|c|c|c|c|c|}
\hline \multirow{2}{*}{ Ranking } & \multicolumn{2}{|c|}{ TOPSIS } & \multicolumn{2}{c|}{ SAW } \\
\cline { 2 - 5 } & Alternatif & Nilai Preferensi & Alternatif & Nilai Preferensi \\
\hline 1 & $\mathrm{P} 12$ & 0.8489 & $\mathrm{P} 12$ & 0.9575 \\
\hline 2 & $\mathrm{P} 13$ & 0.8091 & $\mathrm{P} 13$ & 0.9375 \\
\hline 3 & $\mathrm{P} 5$ & 0.7179 & $\mathrm{P} 5$ & 0.9175 \\
\hline 4 & $\mathrm{P} 14$ & 0.7110 & $\mathrm{P} 14$ & 0.9175 \\
\hline 5 & $\mathrm{P} 15$ & 0.7062 & $\mathrm{P} 15$ & 0.9075 \\
\hline 6 & $\mathrm{P} 11$ & 0.6660 & $\mathrm{P} 6$ & 0.8975 \\
\hline 7 & $\mathrm{P} 10$ & 0.6484 & $\mathrm{P} 11$ & 0.8975 \\
\hline 8 & $\mathrm{P} 8$ & 0.6214 & $\mathrm{P} 10$ & 0.8825 \\
\hline 9 & $\mathrm{P} 9$ & 0.6013 & $\mathrm{P} 9$ & 0.8775 \\
\hline 10 & $\mathrm{P} 6$ & 0.5839 & $\mathrm{P} 8$ & 0.8675 \\
\hline 11 & $\mathrm{P} 1$ & 0.5017 & $\mathrm{P} 1$ & 0.8375 \\
\hline 12 & $\mathrm{P} 7$ & 0.4745 & $\mathrm{P} 7$ & 0.81 \\
\hline 13 & $\mathrm{P} 4$ & 0.4281 & $\mathrm{P} 4$ & 0.7275 \\
\hline 14 & $\mathrm{P} 3$ & 0.3176 & $\mathrm{P} 3$ & 0.7075 \\
\hline 15 & $\mathrm{P} 2$ & 0.2489 & $\mathrm{P} 2$ & 0.69 \\
\hline
\end{tabular}

Dari hasil perhitungan metode TOPSIS dan SAW, dapat terlihat kedua metode memberikan urutan peringkat kepada alternatif yang hampir serupa. Metode TOPSIS juga dapat menghasilkan angka desimal berbeda daripada angka desimal dari perhitungan metode SAW. Hal itu dapat dilihat pada kasus alternatif P5 dan P14. Dimana metode TOPSIS mampu memberikan nilai preferensi untuk P5 = 0.7179 dan $\mathrm{P} 11=0.7110$ dibandingkan dengan hasil nilai preferensi dari metode SAW yang memberikan nilai preferensi untuk P5 dan P11 adalah sama yaitu 0.9175 .

Untuk kasus P11 dan P6 terlihat perbedaan yang signifikan antara dua metode tersebut. Pada metode TOPSIS P11 mendapat peringkat 6 dan $\mathrm{P} 6$ mendapat peringkat 10 , sedangkan metode SAW memberikan P6 dan P11 peringkat 6 dan 7. Jika dilihat dari definisi konsep TOPSIS sendiri yang menunjukan bahwa alternatif yang terbaik memiliki jarak terpendek dari solusi ideal positif dan jarak terjauh dari solusi ideal negatif. Data nilai (tabel 1) dari alternatif P11 dan P6 jika dijumlahkan akan memiliki total nilai yang sama, tetapi terdapat perbedaan pada hasil perhitugan pada kandidat solusi positif dan kandidat solusi negatif C2, C5, dan C8 pada kedua alternatif tersebut (Langkah 3, perhitungan TOPSIS). Perbedaan dapat dilihat pada tabel 9.

Tabel 9. Perbandingan Kandidat Solusi Positif Dan Negatif P6 Dan P11 Pada C2, $\mathrm{C} 5, \mathrm{C} 8$

\begin{tabular}{|c|c|c|c|}
\hline & C2 & C5 & C8 \\
\hline P6 & 0.0143 & 0.0300 & 0.0305 \\
\hline P11 & 0.0179 & 0.0180 & 0.0406 \\
\hline $\left.\operatorname{Max} \mathbf{( A ~}^{+}\right)$ & 0.0179 & 0.0300 & 0.0508 \\
\hline
\end{tabular}

Pada alternatif P11, kriteria C2 dan C8 memiliki jarak yang cukup dekat dengan solusi ideal positif $\left(A^{+}\right)$, sedangkan pada 
alternatif P6, hanya pada kriteria C5 yang menunjukan bahwa nilai tersebut adalah solusi ideal positif $\left(\mathrm{A}^{+}\right)$. Perbedaan jarak tersebut yang menyebabkan kedua alternatif tersebut memiliki peringkat yang berbeda, walaupun kedua alternatif tersebut memiliki jumlah nilai (tabel 1) yang sama.

Berikut adalah grafik persebaran nilai preferensi yang dihasilkan dari metode TOPSIS dan SAW.

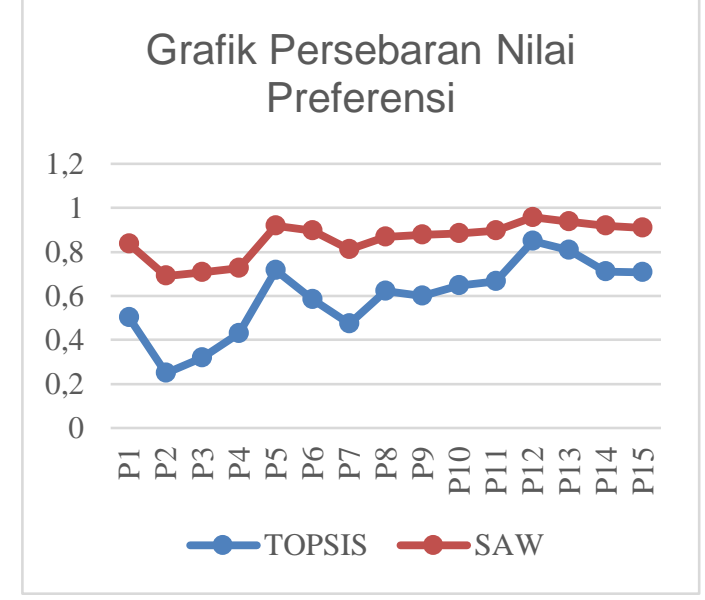

Gambar 2. Grafik persebaran nilai preferensi dari metode TOPSIS dan SAW

Dari gambar 2 terlihat bahwa persebaran nilai preferensi yang dihasilkan oleh metode TOPSIS lebih tersebar dan variatif dibandingkan dengan persebaran nilai preferensi yang dihasilkan oleh metode SAW. Dengan persebaran nilai preferensi yang lebih baik, manajer tempat studi kasus mampu memberikan batas nilai yang baik dan batas nilai yang buruk atau batas minimal nilai yang dianggap baik.

\section{Kesimpulan}

Penelitian ini dilakukan dengan tujuan untuk menganalisis dan membandingkan hasil output peringkat dari perhitungan dengan menggunakan metode TOPSIS dan metode SAW. Dari hasil penelitian yang telah dilakukan, dapat dikatakan bahwa TOPSIS memberikan nilai preferensi yang lebih bervariasi (tersebar) dibandingkan dengan metode SAW. Dalam segi peringkat yang dihasilkan dari kedua metode tersebut tidak jauh berbeda. Dari kedua metode tersebut hanya pada peringkat 6-10 yang menunjukan beberapa perbedaan peringkat, yaitu pada P6 dan P11. Metode TOPSIS diharapkan dapat menjadi metode alternatif pengganti dari metode SAW yang sudah berjalan pada PT
Pura Barutama Unit Paper Mill 5, 6, 9. Dikarenakan TOPSIS mampu menghasilkan nilai akhir yang lebih variatif, dan TOPSIS sendiri adalah metode SPK yang sudah populer dalam berbagai bidang pekerjaan. Pergantian metode SAW ke TOPSIS diharapkan dapat menghasilkan nilai yang lebih relevan dan lebih bervariatif untuk menunjukan karyawan mana yang patut diberi apresiasi dan yang tidak. Diharapkan kedepannya penelitian ini dapat dikalkulasi ulang dengan bobot yang berbeda ataupun dibandingkan dengan metode SPK lain, seperti AHP, PROMENTHEE, ELECTRE, atau metode SPK lainnya.

\section{Referensi}

Adi, P. T. K., Sugiharti, E., \& Alamsyah, A. (2018). Comparison Between SAW and TOPSIS Methods in Selection of Broiler Chicken Meat Quality. Scientific Journal of Informatics, 5(1), 81-90. https://doi.org/10.15294/sji.v5i1.14416

Aeni Hidayah, N., \& Fetrina, E. (2017). RANCANG BANGUN SISTEM PENDUKUNG KEPUTUSAN KENAIKAN JABATAN PEGAWAI DENGAN METODE PROFILE MATCHING (Studi Kasus: Kementerian Agama Kantor Wilayah DKI Jakarta). Studia Informatika: Jurnal Sistem Informasi, 10(2), 127134.

Annette, R., Banu W, A., \& Chandran P, S. (2018). A Multi Criteria Recommendation Engine Model for Cloud Renderfarm Services. International Journal of Electrical and Computer Engineering (IJECE), 8(5), 3214-3220.

https://doi.org/10.11591/ijece.v8i5.pp3 214-3220

Anwar, F., Masud, M. H., UI Islam Khan, B., Olanrewaju, R. F., \& Latif, S. A. (2018). Radio Access Technology (RAT) Selection Mechanism using TOPSIS Method in Heterogeneous Wireless Networks (HWN). Indonesian Journal of Electrical Engineering and Computer Science, 12(2), 852-864. https://doi.org/10.11591/ijeecs.v12.i2. pp852-864

Auxyllian, A. A. V., \& Susetyo, Y. A. (2019). Perancangan Sistem Penilaian 
Karyawan Menggunakan Framework Laravel Berbasis Simple Additive Weighting (Studi Kasus PT Pura Barutama Unit Paper Mill 5, 6, 9).

Bambang, D., Wijaya, T., Wahyono, T., Nugrahesthy, A., \& Hapsari, S. (2019). TOPSIS Method Implementation for Employee Performance Information System. International Journal of Information Technology and Business, 2(1), 21-26.

Bogdanovic, D., \& Miletic, S. (2015). Personnel Evaluation and Selection by Multicriteria Decision Making Method. Economic Computation and Economic Cybernetics Studies and Research, 48(3).

Evita, S. N., Muizu, W. O. Z., \& Atmojo, R. T. W. (2017). Penilaian Kinerja Karyawan Dengan Menggunakan Metode Behaviorally Anchor Rating Scale dan Management by Objectives (Sudi kasus pada PT Qwords Company International). Pekbis Jurnal, 9(1), 18-32.

Guarini, M. R., Battisti, F., \& Chiovitti, A. (2018). A Methodology for the Selection of Multi-Criteria Decision Analysis Methods in Real Estate and Land Management Processes. Sustainability (Switzerland), 10(2). https://doi.org/10.3390/su10020507

Mohamed, E. M., Bouikhalene, B., Ouatik, F., \& Safi, S. (2019). AHP and TOPSIS methods applied in the field of scientific research. Indonesian Journal of Electrical Engineering and Computer Science, 14(3), 1382-1390. https://doi.org/10.11591/ijeecs.v14.i3. pp1382-1390
Rahim, R., Supiyandi, S., Siahaan, A. P. U., Listyorini, T., Utomo, A. P., Triyanto, W. A., ... Khairunnisa, K. (2018). TOPSIS Method Application for Decision Support System in Internal Control for Selecting Best Employees. Journal of Physics: Conference Series, 1028(1). https://doi.org/10.1088/17426596/1028/1/012052

Setiobudi, E. (2017). Analisis Sistem Penilaian Kinerja Karyawan Studi pada PT. Tridharma Kencana. JABE (Journal of Applied Business and Economic), 3(3), 170-182. https://doi.org/10.30998/jabe.v3i3.176 8

Velasquez, M., \& Hester, P. T. (2013). An Analysis of Multi-Criteria Decision Making Methods. International Journal of Operations Research, 10(2), 55-66. https://doi.org/10.1007/s13748-0160093-1

Widianta, M. M. D., Rizaldi, T., Setyohadi, D. P. S., \& Riskiawan, H. Y. (2018). Comparison of Multi-Criteria Decision Support Methods (AHP, TOPSIS, SAW \& PROMENTHEE) for Employee Placement. Journal of Physics: Conference Series, 953(1). https://doi.org/10.1088/17426596/953/1/012116

Wira Trise Putra, D., \& Agustian Punggara, A. (2018). Comparison Analysis of Simple Additive Weighting (SAW) and Weigthed Product (WP) in Decision Support Systems. In MATEC Web of Conferences (Vol. 215, pp. 1-5). https://doi.org/10.1051/matecconf/201 821501003 